\title{
The Value of Clean Hands: \\ Public Policy and International Asset Allocation
}

\author{
Piet Sercu and Rosanne Vanpée*
}

June 7, 2011

${ }^{*}$ Rosanne Vanpée, the corresponding author is at Hogeschool-Universiteit Brussel, Piet at Katholieke Universiteit Leuven, Research Center International Finance, Belgium. E-mail addresses: Rosanne.vanpee@hubrussel.be, Piet.sercu@econ.kuleuven.be 


\begin{abstract}
Despite of the intuitive idea that corporate governance and transparency are crucial for a country's international appeal, foreign portfolio investors appear to care first and foremost about transparency, predictability and honesty in governments. This is, at least, what our analysis of international portfolio holdings implies. Our estimates further indicate that (i) a feasible improvement of government corruption, economic policy transparency and especially institutional quality can trigger an economically substantial rise in foreign interest for the stocks of that country; and (ii) an amelioration in country-level governance variables creates significantly higher effects on foreign equity demand than an improvement in traditional macroeconomic policy indicators.
\end{abstract}

JEL classification: G15, G18, G30, G38, F3

Keywords: Corporate governance, government effectiveness, institutional quality, international capital flows, international equity allocation 


\section{The Value of Clean Hands:}

\section{Public Policy and International Asset Allocation}

\section{Introduction}

This paper assesses how much additional portfolio investment could be attracted by a modest improvement in country level governance and simple macroeconomic policy indicators. The first issue is at what level transparency matters most, the country or the firm, and how these interact. We find that the effect of government transparency on international asset allocation is far more pronounced than the effect of corporate transparency. Similar to Doidge, Karolyi and Stulz (2007), our study shows as positive interaction between corporate and country-level governance.

Given that country-level governance matters more for aggregate international portfolios than corporate governance, we focus on the effects of public policy-making on international asset demand. We distinguish between governance variables - notably the level of perceived public corruption, economic policy transparency and institutional quality - and traditional macroeconomic policy indicators, notably the Misery Index, the government deficit and the balance on the current account. Our assessment is that improved transparency and credibility in the public sector lead to a substantial additional foreign demand for a country's equities. Improving macroeconomic policy-making leads to more modest inflows into the equity markets: the demonstrable effect of improving government transparency on international asset allocation seems at least ten times larger than the effect of further improvement in factors that influence economic activity directly. The large effect on demand is linked to the fact that countries with weak government institutions and public transparency are typically countries with small and less developed financial markets. A feasible improvement in these countries' public policy transparency leads to a significant decrease in implicit inward portfolio investment costs and an additional foreign demand that is large compared to their initial market capitalization. The relatively small effect on demand following a change in macroeconomic variables reflects the fact that for most countries in our sample have already adopted better macroeconomic policies in the sense of the Washington Consensus; that is, a lot of work in that field has already been done. By contrast, they still perform poorly compared to the industrialized countries in areas as institutional quality and transparency of public policy-making, leaving more room for improvement.

Methodologically, the main difference with prior studies is that we use portfolio theory rather than an ad hoc regression to forecast asset demand. The results therefore take into account diversifiable versus undiversifiable risks.

The remainder of the paper is structured as followed. In Section 1, we provide an overview of the relevant literature. In Section 2, we briefly review the model of international portfolio holdings with deadweight costs of foreign investments of Cooper and Kaplanis $(1994,2000)$ and show how the effect of a change in the variables on the asset allocation of investors is computed. Section 3 describes the data. Section 4 discusses estimates of the effect of an improvement in 
government transparency and macroeconomic policy-making in particular on the shadow costs of foreign investments and the resulting new asset allocation. The final section concludes.

\section{Literature review}

We first cover some recent work on the impact of good governance and the quality of institutions on financial development in general. In a second part, we discuss the literature on the effect of corporate and government transparency on international portfolio flows in particular.

\subsection{Governance and financial development}

The Washington Consensus, initiated by John Williamson in 1990, started as a set of ten macroeconomic policy prescriptions that were believed to be necessary for the recovery of the Latin American countries from the financial crises of the 1980s. Later, the Consensus evolved into a general guideline promoting economic liberalization and free mobility of capital. The prospect offered by the Washington Consensus was that if a developing country would implement conservative macroeconomic and liberal microeconomic policies to expand the role of the private market at the expense of the state in resource allocation, it would achieve sustained high growth rates and a well developed financial market (Woo, 2004).

The Washington Consensus is striking in its free-market approach, even in fields where market failure is not unthinkable. For the financial sector, for instance, the risks are many. First, foreign investors are more prone to feedback trading and herding behavior than domestic investors, which can destabilize financial markets, especially in developing countries (Choe, Kho and Stulz, 1999). Second, foreign investors may engage in speculative attacks on developing countries' currencies. Third, there is a larger risk of contagion: foreign investors could withdraw capital from initially healthy countries for reasons unrelated to domestic factors (Prasad et al., 2003). Additional volatility can be disruptive and costly (Eichengreen, 2004). At the end of the nineties, crises in East Asia, Russia and Brazil highlighted the link between weak governance, poor institutional quality in emerging markets and financial stability. Another example is Argentina, a country that has more or less played by the rules of the Washington Consensus, has been hit by financial crises, hyperinflation and capital flight in 2002. As a result, an intense debate has emerged on the effects of financial integration for developing economies. In a paper written on behalf of the Copenhagen Consensus, Eichengreen (2004) lists the causes of financial instability in the developing countries. These include unsustainable macroeconomic policies, fragile financial systems, institutional weakness and flaws in the structure of international financial markets. Some authors argue that adequate microeconomic and macroeconomic policies are necessary but not sufficient conditions for eliminating vulnerabilities. Prasad, Rogoff, Wei and Kose (2003) find that the quality of domestic governance, proxied by the rule of law, corruption, and political polarization play a crucial role in allowing financial globalization to boost economic growth rather than holding it back. Wyplosz (2004) states that good policies are a prerequisite for successful liberalization which, in turn, presupposes good governance: good governance delivers better economic policies which then promote 
growth. Johnson, Boone, Breach and Friedman (2000) and Acemoglu, Johnson, Robinson and Thaicharoen (2003) find that macroeconomic variables have less power in explaining the variation in the depth of financial crises across countries than corporate transparency variables or institutional quality measures. Stulz (2005) reasons that opening borders to foreign investors and cutting transaction costs is not sufficient to create large shifts in international asset allocation. Poor governance in certain countries and firms stops investors from placing their money there where the return is most likely to be higher, because third parties pick off the gains before they are received by the investor. The merits of a good governance at both the firm-level and the country-level have been studied extensively (amongst others Shleifer and Vishny, 1997; Bhattacharya, Daouk and Welker, 2003; Wei, 2000a, 2000b). A more extensive literature review can be found in Fergusson (2006).

The debate on the importance of good governance on both the company and the country level has grown intensively in the wake of the 2007-2009 credit crisis. The crisis, that started in the developed economies as a result of the collapse of the real estate market and excessive risk taking of financial institutions under the form of massive securitization, quickly spread to the emerging markets, where it hit even harder. Some researchers have attributed the collapse of the financial sector to failures in corporate governance. Kashyap, Rajan and Stein (2008) argue that the root of the crisis was in the breakdown of shareholder monitoring and ill conceived managerial incentives. Similarly, Kirkpatrick (2009) concludes that "the financial crisis can be to an important extent attributed to failures and weaknesses in corporate governance arrangements." Erkens, Hung and Matos (2009) point out an important weakness in the corporate governance structure. Erkens et al. show that firms with more independent boards and greater institutional ownership emphasize short term profits more strongly and engage in excessive risk taking compare to firms with corporate insiders as shareholders. They show empirically that this deficiency in corporate governance mechanisms has played a crucial role in the financial crisis. However, a convincing argument against weak governance being at the root of the crisis is the empirical observation that banks with both weak and strong governance systems collapsed and that the financial system crashed in countries with both weak and strong shareholder protection. Beltratti and Stulz (2009) show that the performance of banks during the credit crisis is unrelated with country governance indicators and, strikingly, banks with more pro-shareholder boards performed worse during the crisis. In general, the recent credit crisis has learned us that even in countries with good governance standards, the current laws and practices on investor protection are still flawed or at least incomplete. Good governance systems as described in the Copenhagen Consensus doesn't seem to be a guarantee for economic and financial success.

\subsection{Governance and international equity flows}

There is convincing evidence that corporate governance and transparency at the companylevel and political risk at the country-level can be drivers for the equity home bias. ${ }^{1}$ A lack

\footnotetext{
${ }^{1}$ Excellent reviews on the home bias puzzle can be found in Lewis (1999) and Karolyi and Stulz (2003).
} 
of transparency leads to information asymmetries, adding complexity and imposing an additional burden on investors' expected returns. Information acquisition costs are much higher for companies that lack adequate accounting and governance practices and that provide little protection to minority shareholders. Dahlquist, Pinkowitz, Stulz and Williamson (2003) show that part of the home bias can be explained by the fact that a portion of a company's shares are held by controlling shareholders, and thus only a fraction of the shares is freely available for foreign investors. In the same line, Giannetti and Simonov (2006) find empirically that investors who enjoy only security benefits - notably domestic or foreign institutionals and small individual investors - are reluctant to invest in companies with bad corporate governance. In contrast, individuals who have strong connections with the local financial community (because they are board members or hold large blocks of at least some listed companies) behave differently. They do not care about the expected extraction of private benefits or even prefer to invest in firms where there is more room for it.

Firm-level governance and country-level governance are closely related. A good legal system limits the rights of managers and discourages them from extracting private benefits. Simultaneously, it provides a mechanism for investors and shareholders to exercise their rights in the firm (Shleifer and Vishny, 1997). A sufficient level of economic and financial development in a country is necessary for a firm to raise funds on the capital markets and be able to benefit from better governance. Gelos and Wei (2005) conclude that both government and corporate transparency positively influence international portfolio holdings, but the effect of government transparency is more pronounced. Doidge, Karolyi and Stulz (2007) find that for countries with poor country-wide governance, firm-level governance and country-level governance are complements. If the government does not provide a reliable legal and financial system, it will be too costly for firms to bond themselves to better governance, since they cannot guarantee investor protection. Stulz (2005) distinguishes between two agency problems: on the one hand, there is the agency problem of corporate-insider discretion, meaning that corporate insiders can expropriate outside investors by extracting private benefits from the firm. On the other hand, there is the agency problem of state-ruler discretion, that is, the risk of expropriation by actions that state rulers take to improve their welfare by reducing the return on corporate investments. Stulz then shows both theoretically and empirically that there is a positive correlation between the two agency problems: ownership concentration increases if the importance of the state ruler agency problem increases and a dispersed firm ownership is inefficient when expropriation by the state is significant. In a similar context, Kho, Stulz and Warnock (2009) show that in countries with weak governance and weak institutions, concentrated ownership is optimal. La Porta, Lopez-de-Silanes, Shleifer and Vishny $(1998,1999)$ had effectively found that company ownership is more dispersed in countries with a good legal protection of minority shareholders.

In contrast, other authors find that corporate governance is a substitute for good country governance rather than a complement. Klapper and Love (2004) and Durnev and Kim (2005) state that in countries with weak legal and policy-making institutions, firms search for alternative solutions to guarantee investor protection, such as establishing good corporate governance practices. Black (2001) finds that firm-level governance can have a huge effect on the market value of Russian firms. Most tests on U.S. firms find no clear relationship between the 
variations in corporate governance behavior and firm value; but, Black argues, for developing countries good corporate governance is especially important.

\section{The shadow costs of international equity positions}

In this section, we briefly review the international portfolio holdings model with shadow costs for international investments developed by Cooper and Kaplanis (1994, 2000), and generalized by Sercu and Vanpée (2008, henceforth SV).

We consider a world with $N$ countries and $N$ currencies. There are $N$ risky equity assets, $N-1$ foreign currency bills or notes and a risk-free asset $2 N$. Cooper and Kaplanis (1994) propose a model for international equity holdings where a representative investor from country $l$ experiences a proportional deadweight loss $C_{i}^{l}$ to invest in a stock of foreign country $i$. Under these assumptions, the net return on asset $i$ for the representative investor of country $l$ is:

$$
R_{i}^{l}:=\left(\mu_{i}-C_{i}^{l}\right) \mathrm{d} t+\sigma_{i} \mathrm{~d} z_{i}, \quad i=1, \ldots, 2 N-1,
$$

where $\mu_{i}$ and $\sigma_{i}$ are the annualized expectation and standard deviation of the nominal rate of return on this asset respectively, and $\mathrm{d} z_{i}$ is the increment to a standard Wiener process. The resulting vector of optimal portfolio holdings is:

$$
x^{l}=\alpha \Omega^{-1}\left(\mu-r \underline{1}-C^{l}\right)+(1-\alpha) \Omega^{-1} w^{l},
$$

where

$x^{l}$ denotes the $(2 N-1) \times 1$ vector of the proportions of investor l's wealth invested in each risky asset,

$\mu$ denotes the $(2 N-1) \times 1$ vector of $p$. $a$. expected returns on the risky assets,

$r$ denotes the p.a. risk-free rate of the reference country,

$\alpha$ denotes the parameter of relative risk tolerance,

$\Omega$ denotes the $(2 N-1) \times(2 N-1)$ covariance matrix of the $p . a$. nominal rates of return on the risky securities,

$\underline{1}$ denotes the $(2 N-1) \times 1$ vector of elements all equal to unity, and

$w^{l}$ denotes the $(2 N-1) \times 1$ vector of covariances of the risky asset returns with investor l's rate of inflation.

In $\mathrm{SV}$, the vector of shadow costs, $C^{l}$, is structured in the following way:

$$
C_{i}^{l}=\left\{\begin{array}{lll}
0 & , \text { if } i \leq N \text { and } i=l, & \text { (domestic stocks) } \\
C\left(h_{l}, f_{i}, a_{l, i}\right)>0 & , \text { if } i \leq N \text { and } i \neq l, & \text { (foreign stocks) } \\
0 & , \text { if } i>N & \text { (fixed-interest). }
\end{array}\right.
$$


This is similar to CK, with the addional specification that the shadow costs of investing abroad are associated with three classes of instruments: home-country related instruments $h_{l}$, host country related instruments $f_{i}$, and an interaction effects, $a_{i, l}$. For riskfree lending and borrowing there is assumed to be no cost.

SV further refine the Cooper-Kaplanis model by first considering hedged stock returns, so as to properly account for exchange rate risk and omitted stock markets from the sample. These hedged stock returns are the residuals of a regression of a stocks' return on the $N-1$ exchange rate changes and the equity returns of the missing markets. SV premultiply equation (2) by (minus) the covariance matrix of returns from hedged stocks, $\Omega_{S \mid X}$, and denote the resulting vector of conditional covariance risks by $y^{l}:=-\Omega_{S \mid X} x^{l}$. They then show that expected returns can be eliminated and shadow costs can be extracted from the international portfolio holdings model by subtracting the domestic portfolio covariance risk from the covariance of the foreign asset with the return on the portfolio of the domestic investor.

$$
\begin{aligned}
y_{i}^{l}=\alpha\left(-R_{e, S_{i}}+C\left(h_{l}, f_{i}, a_{l, i}\right)\right. & \left.+\Gamma_{i}^{\prime} R_{e, X}\right)-(1-\alpha) w_{S_{i} \mid X}^{l}, \\
y_{i}^{i}=\alpha\left(-R_{e, S_{i}}\right. & \left.+\Gamma_{i}^{\prime} R_{e, X}\right)-(1-\alpha) w_{S_{i} \mid X}^{i}, \\
\Rightarrow\left(y_{i}^{l}-y_{i}^{i}\right) & =\alpha\left[C\left(h_{l}, f_{i}, a_{l, i}\right)\right]-(1-\alpha)\left(w_{S_{i} \mid X}^{l}-w_{S_{i} \mid X}^{i}\right),
\end{aligned}
$$

where

$-y_{i}^{l}:=\operatorname{cov}\left(R_{i}^{h}, R_{p(l)}\right)$, the conditional covariance of hedged stock $i$ 's return with the return on the portfolio held by investor $l$,

$C$, the vector of shadow costs, reflects home country-related costs $h_{l}$, foreign-country related $\operatorname{costs} f_{i}$, and interaction variables $a_{l, i}$ between the home and host country,

$w_{S_{i} \mid X}^{l}:=\operatorname{cov}\left(R_{i}^{h}, \Pi^{l}\right)$, the conditional covariance between the hedged return of stock $i$ with investor l's inflation rate,

$R_{e, S_{i}}$ and $R_{e, X}$ denote the excess returns on stocks and bonds respectively, and

$\Gamma$ is the matrix of hedge ratios.

There are as many elements in $C$ as there are $(l, i)$ pairs (and, therefore, observed $x_{i}^{l}$ 's per cross-section) and also $\alpha$ is unknown. As a result, point estimates of costs can be backed out only if $\alpha$ is known. This is essentially what Cooper and Kaplanis (1994) do: they postulate various values for $\alpha$ and compute the corresponding implied costs. SV in contrast, replace $C$ by a projection on a much smaller number of instruments $H, F$ and $A$ that have been proven to be correlated with home bias. Since this economizes on degrees of freedom, they are able to estimate $\alpha$ from the same data. SV assume an exponential cost structure such that all fitted values are strictly positive and the effect of alpha on the coefficient estimates is minimal. Thus, denoting $X:=[H, F, A]$ the regression for the $\mathrm{SV}$-model is:

$$
\left(y_{i}^{l}-y_{i}^{i}\right)_{t}=\alpha \times \exp \left(c+\sum \beta_{j} X_{j}\right)_{t}+(1-\alpha)\left(w_{S_{i} \mid X}^{i}-w_{S_{i} \mid X}^{l}\right)_{t} .
$$




\subsection{The impact of a shadow cost differential on international equity demand}

To calculate the influence of a change in the costs factors on the international equity demand, we start from equation (2), $\mathrm{r}$ which we multiply on both sides by the investing country's wealth $W^{l}$, which is sum of the country's total bond holdings and total equity holdings. This way we obtain a demand expressed in dollars rather than portfolio weights:

$$
W^{l} x^{l}=W^{l}\left[\alpha \Omega^{-1}\left(\mu-r \underline{1}-C^{l}\right)+(1-\alpha) \Omega^{-1} w^{l}\right] \text { where } C^{l}=\exp \left(\hat{c}+\sum \hat{\beta}_{j} X_{j}\right) .
$$

Using the estimated coefficient estimates and the values of the variables $X$ in equation (5), we

can compute the cost $C^{l}$ for the observed $X$ and a cost $C_{\text {new }}^{l}$ for a modified set $X_{\text {new }}$. The corresponding change in demand for equity from country $l$ equals

$$
W^{l} \Delta x^{l}=W^{l} \alpha \Omega^{-1}\left(C_{n e w}^{l}-C^{l}\right) .
$$

Note that this is purely a demand-side approach; how this demand is met cannot be specified from the model. Presumably, improved governance or better macroeconomic policies should improve future cash flows and thus increase prices. In the medium run, also new issues can help meet the increased demand. A pure price hike (without new issues or improved cash flows) is also conceivable; but this would imply either a change in the expected returns or some irrationality, neither of which is strictly compatible with the model. Note also that this is a "first-round" prediction: there should also be interesting feedback mechanisms if changed asset demand affects prices and thus wealths, but these feedbacks cannot be quantified using portfolio theory. The impact of feedback on worldwide demand must be minimal, though: the main beneficiaries would be emerging-country investors, who represent only a small fraction of world invested financial wealth.

The neglect of feedback via increased wealth is not the only reason why the estimated changes of the implicit costs and the resulting shift in foreign demand should be interpreted as indicative only. A second reason why the predictions are conservative is that transparency variables are correlated and one would expect for example that an improvement in the transparency of economic policy would also lower the perception of corruption in the public sector. This would then reinforce the positive effect on the shadow costs of inward investment and further improve international demand for the country's assets. Transparency variables are also correlated to other information-related cost factors. It has been shown that the negative effects of a financial crisis in a country, that is the large capital flight of foreigners and the loss in confidence by investors in the equity markets, are much worse in countries with a bad corporate governance and a weak legal system (Gelos and Wei, 2005; Johnson, Boone, Breach and Friedman, 2000). Lastly, improved governance or policy-making may also lead to a drop in required returns and/or risks which would further boost demand. However, there is no obvious way that a mean-variance model can predict such an effect.

In terms of the twin agency problem of Stulz (2005), we study the effect of a decrease in the agency problem of state-ruler discretion on the demand of foreign investors for a country's equities. This decrease in the state agency problem can have two side-effects. First, any improvement in the transparency of the public policy or any reduction in the level of public corruption should decrease the controlling shareholder discretion since, for instance, controlling 
shareholders can no longer get away with expropriation of minority shareholders by bribing state rulers. Second, there can be positive side-effects on the concentration of controlling shareholders in the firm. A substantial increase in foreign demand towards a country's equities can lead to a rise in the stock prices. If the price of a company's share is high enough, inside investors become more willing to sell part of their shares, resulting in a more dispersed shareholder structure. Thus, the improvement in government transparency variables can change the quality of corporate governance and also its impact on international asset allocation. However, we do not study these side-effects in this paper. For all these reasons our forecasted increases in demand are conservative.

To compare the impact of changes in these variables on foreign demand we cannot just look at the regression coefficients because, even for given $\Delta X$, the result depends on on the inverse of $\Omega$, the covariance matrix of asset returns. For instance, a given change in e.g. the corruption index has a smaller impact if the country is a high-variance one. In addition, the impact depends also on the size of the change in the instrument under consideration. So we need to come up with a set of changes in the instruments $X$ that are feasible and of comparable economic significance across instruments. One could think of a one-sigma change, but this would mean that a country that already does well is expected to realize the same change in $X$ as one that does quite poorly. Instead, we only look at underperforming countries, and let these reduce the observed distance to the median of $X$ by one fourth. Thus, we rank our sample countries on each of the government-opacity and macroeconomic variables and we focus on the countries that score worse than the median. In most cases, these are emerging markets. For each such country, we then administer the improvement. For instance, if a higher score of a variable $X$ is associated with worse policies, the change is:

$$
X_{\text {new }}=X-\frac{\operatorname{Max}(X-\operatorname{Median}, 0)}{4} .
$$

We then calculate the new set of shadow costs. Next, we calculate for each investing country $l$ the new demand for stock of all destination countries $i$, and we sum across $l$ s so as to find the extra world demand for country $i$ 's stocks.

\section{Data}

We use annual portfolio holdings data from 2005 to 2009 for a sample of 42 countries. We try to capture the dynamics of return volatilities by estimating the TGARCH (threshold GARCH) model proposed by Bekeart and Harvey (1997), see Appendix. This provides us with a time series of variances. For the covariances we use the CCC (Constant Conditional Correlation) approach of e.g. Bollerslev (1990) and Longin and Solnik (1995). That is, we specify the conditional correlation matrix of stock returns to be the correlation matrix of the standardized unexpected country returns:

$$
\operatorname{cov}_{l, i, t}=\rho_{l, i} \sigma_{l, t} \sigma_{i, t}
$$

where $\rho_{l, i}$ is the correlation between the standardized unexpected equity returns of country $l$ and country $i$. 
Data on stock prices and exchange rates from 1996 to 2009 are obtained from Datastream. The Bekaert-Harvey model requires a set of domestic and world information variables to estimate the conditional mean returns and variances. For the world market dividend yield and the country dividend yields, we use the dividend yields of the Datastream Global Indices. Moody's bond yield are from the Federal Reserve Data Release, and Eurodollar rates, US bond and Tbill yields are from Datastream. Data on exports, imports and GDP are also retrieved from Datastream.

Data on international portfolio holdings in equities and bonds are from the Coordinated Portfolio Investment Survey (CPIS), conducted by the IMF. We use portfolio holdings data for 42 countries for each of the years 2005 to 2009. To obtain an estimate for the total wealth portfolio, we combine the aggregate equity holdings with the aggregate bond holdings for each country. Domestic stock market capitalizations for each year end are from the World Federation of Exchanges (http://www.world-exchanges.org) and bond market capitalizations are from the Bank of International Settlements Security Statistics (http://www.bis.org/statistics/secstats.htm). Domestic equity holdings are calculated as the difference between a country's equity market capitalization and its foreign holdings of these equities. The country's total equity holdings are equal to the sum of its domestic equity holdings and the total amount invested in foreign equities reported in the CPIS. Domestic and total bond holdings are calculated in a similar way. Total invested wealth is the sum of the total equity and bond portfolio of each country. Following SV, investments in off-shore financial centers are reallocated over the sample countries in proportion to the foreign investments of these centers. ${ }^{2}$

The instruments used to capture the shadow costs of international investments have been used before in studies that try to explain international portfolio holdings directly, like Chan, Covrig and Ng (2005), Fidora, Fratzscher and Thimann (2007), Lane and Milesi-Feretti (2004, 2005), Berkel (2004), Coval and Moskowitz (1999), Faruqee, Lee and Yan (2004) and Portes and Rey (2005). SV group the instruments into six categories depending on whether they proxy for information asymmetries, explicit frictions, the level of financial development, economic health and stability measures, political risk and corporate governance and return skewness of stocks. We were unable to recuperate the data on explicit transaction costs that were included in the SV study. Also, we decided to leave out the financial crisis dummy as every country in our sample suffered from the 2007-2009 financial crisis. SV use the Insider Trading Index as a corporate governance measure. As this measure is no longer updated in the Global Competitiveness report, we replace this by an index measuring corporate board effectiveness. We add one macroeconomic variable to the instruments of SV, the host country's government surplus or deficit as a percentage of its GDP. Table 1 offers a brief description of the variables used for the projection of the shadow costs of international investments. We estimate deadweight

\footnotetext{
${ }^{2}$ These off-shore financial centers are Aruba, the Bahamas, Bahrain, Barbados, Bermuda, Cayman Islands, Costa Rica, Cyprus, Gibraltar, Guernsey, Ireland, Isle of Man, Jersey, Lebanon, Luxembourg, Macao, Malta, Mauritius, the Netherlands Antilles, Panama and Guernsey. SV show that alternative allocation methods for the investments from and into financial off-shores do not meaningfully affect the estimation results.
} 
The Value of Clean Hands: Public Policy and International Asset Allocation

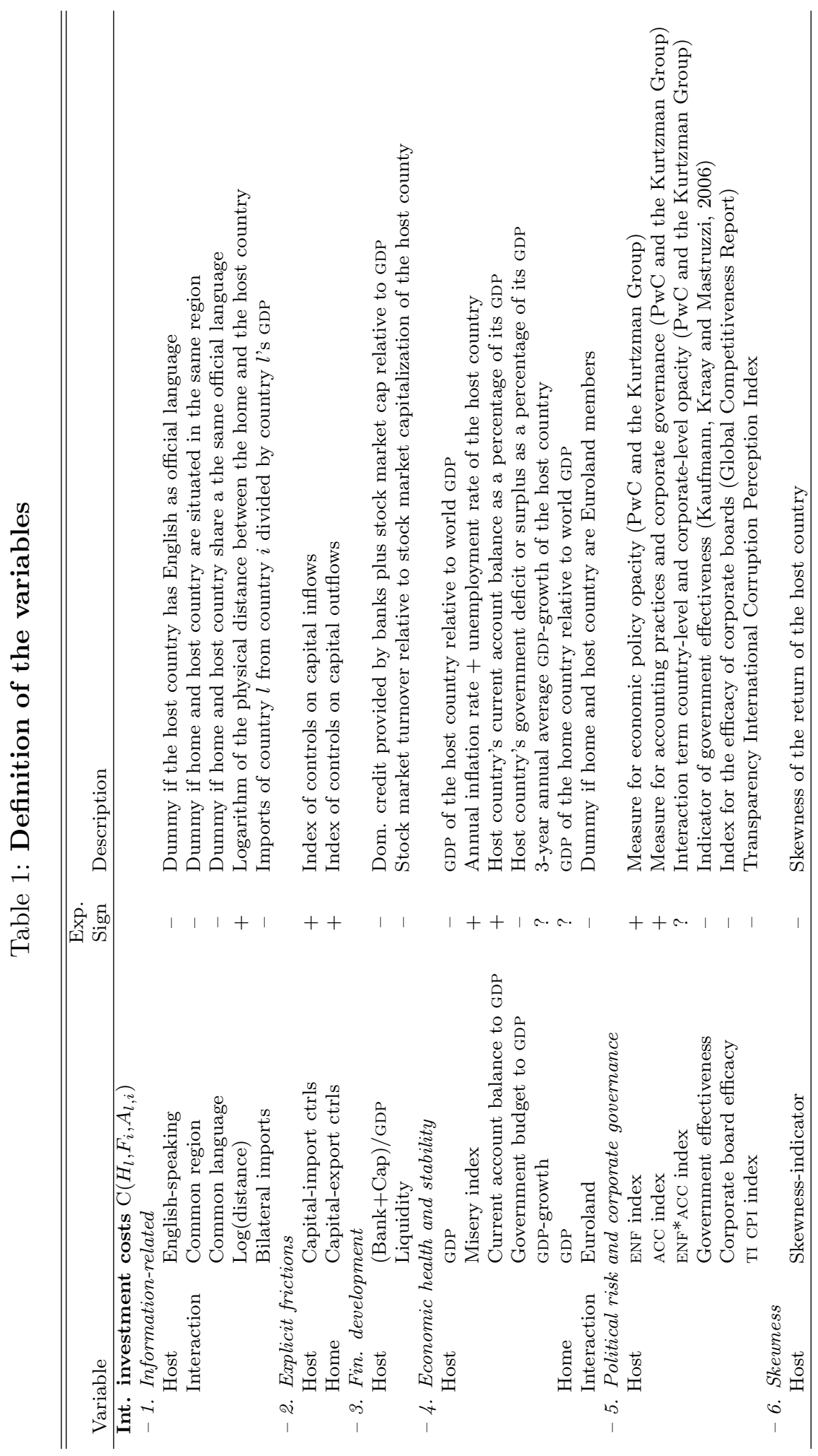


Table 2: Estimation results SV-model

This table shows contains the GMM estimation results of equation (5)for the pre-crisis (2005-2007) and crisis subsample (2008-2009) and for the pooled sample. Investments in financial centers are reallocated over the sample countries in proportion to the reported foreign investments of these centers. Significance at the $99 \%, 95 \%$ and $90 \%$ level is denoted by three, two and one ${ }^{*}$ respectively.

\begin{tabular}{|c|c|c|c|c|c|c|c|c|}
\hline \multirow[b]{2}{*}{ Variable } & \multirow{3}{*}{$\begin{array}{l}\text { Exp. } \\
\text { Sign }\end{array}$} & \multicolumn{2}{|c|}{ 2005-2007 } & \multicolumn{3}{|c|}{ 2008-2009 } & \multicolumn{2}{|c|}{ Pooled } \\
\hline & & coeff & t-stat & coeff & & t-stat & coeff & t-stat \\
\hline Inflation hedging $(\alpha)$ & & 0.78 & *** 7.56 & 0.70 & *** & 4.38 & 0.78 & *** 7.13 \\
\hline Constant $(\log (\alpha)+c)$ & $?$ & -8.56 & $* * *-28.81$ & 0.16 & & 0.47 & -6.47 & $* * *-19.43$ \\
\hline \multicolumn{9}{|l|}{ Int. investment costs $C\left(H_{l}, F_{i}, A_{l, i}\right)$} \\
\hline \multicolumn{9}{|l|}{ - 1. Information-related } \\
\hline$F_{i} \quad$ English-speaking host & - & -0.87 & $* * *-8.95$ & -0.35 & $* * *$ & -3.82 & -0.19 & $* * *-3.18$ \\
\hline Common region & - & -0.16 & $* * *-3.13$ & -0.16 & $* * *$ & -3.06 & -0.28 & $* * *-6.18$ \\
\hline Common language & - & -0.18 & $* * *-4.30$ & -0.20 & **** & -5.15 & -0.05 & * -1.87 \\
\hline $\log ($ distance $)$ & + & 0.09 & $* * * \quad 2.68$ & 0.10 & *** & 2.59 & 0.02 & 1.62 \\
\hline Bilateral imports & - & -0.54 & -0.40 & -0.83 & & -0.77 & -1.47 & -1.23 \\
\hline \multicolumn{9}{|l|}{ - 2. Explicit frictions } \\
\hline$F_{i} \quad$ Dest. capital-import ctrls & + & 0.26 & 6.09 & -0.04 & & -0.91 & 0.17 & 5.79 \\
\hline Home capital-export ctrls & + & -0.06 & $* * *-4.84$ & -0.05 & $* * *$ & -3.33 & -0.04 & $* * *-3.43$ \\
\hline \multicolumn{9}{|l|}{ - 3. Fin. development } \\
\hline$F_{i} \quad($ Bank+Cap $) /$ GDP, abroad & - & -0.03 & $* * *-28.33$ & -0.04 & $* * *$ & -8.92 & -0.03 & $* * *-30.84$ \\
\hline Liquidity abroad & - & 0.63 & *** 18.83 & 1.14 & $* * *$ & 19.88 & 0.72 & $* * * 24.61$ \\
\hline \multicolumn{9}{|l|}{ - 4. Economic health and stability } \\
\hline$F_{i} \quad$ GDP, host & - & -7.81 & $* * *-10.49$ & -9.31 & $* * *$ & -7.69 & -7.47 & $* * * \quad-8.89$ \\
\hline GDP-growth host & $?$ & -2.53 & $* * *-3.65$ & 6.17 & $* * *$ & 5.47 & -5.04 & $* * *-8.65$ \\
\hline Misery index, host & + & 1.60 & ** $\quad 2.09$ & 1.00 & $* * *$ & 9.65 & 1.35 & *** $\quad 2.63$ \\
\hline Current acc balance, host & $?$ & 4.05 & 9.58 & -5.54 & $* * *$ & -14.11 & -3.60 & $* * *-10.53$ \\
\hline Govermnt acc balance, host & - & -2.47 & $* * *-6.11$ & 2.12 & *** & 10.18 & 1.26 & 5.59 \\
\hline Home GDP & ? & 0.32 & ** $\quad 2.07$ & 0.39 & *** & 2.46 & 0.42 & 2.47 \\
\hline Euroland & - & -1.03 & $* * * \quad-7.70$ & -0.84 & $* * *$ & -10.62 & -0.89 & $* * *-13.12$ \\
\hline \multicolumn{9}{|c|}{ - 5. Political risk and corporate governance } \\
\hline$F_{i} \quad$ ENF, host & + & -0.03 & *** 14.34 & 0.04 & $* * *$ & 13.67 & 0.01 & 5.61 \\
\hline ACC, host & + & 0.01 & 0.69 & 0.01 & & 0.66 & 0.01 & 1.45 \\
\hline ENFACC, host & $?$ & 0.10 & *** 10.47 & 0.03 & $* * *$ & 5.25 & 0.05 & 8.95 \\
\hline Government effect., host & - & -1.43 & $* * *-39.25$ & -1.12 & $* * *$ & -7.21 & -1.27 & $* * *-29.92$ \\
\hline Efficacy corp. board, host & - & 1.00 & 1.29 & -0.25 & $* * *$ & -6.37 & 0.35 & 1.27 \\
\hline Corruption, host & - & -0.18 & $* * *-2.39$ & -0.22 & $* * *-$ & -11.38 & -0.19 & $* * *-6.11$ \\
\hline \multicolumn{9}{|l|}{ - 6. Skewness } \\
\hline$F_{i} \quad$ Skewness, host & - & -0.84 & $* * *-24.57$ & 0.50 & *** & 10.29 & -10.07 & $* * *-2.72$ \\
\hline Adjusted $R^{2}$ & & 0.73 & & 0.68 & & & 0.63 & \\
\hline
\end{tabular}

cost model over the five year period 2005-2009, two subperiods 2005-2007 and 2008-2009, and year-by-year. Table 2 reports the coefficient estimates and the t-statistics for equation (5) for the pooled sample and the pre-crisis and crisis period. Estimation results for the year-by-year cross sections are shown in Table 5 in the appendix. We estimate the model using GMM with a Newey-West weighted covariance matrix to account for heteroskedasticity. Note that most cross-country commonalities are already picked up by variables indicating common language, common region, English-speaking countries and Euroland countries. Correlations over time are not an issue for the year-by-year cross sections.

Among the regressors, one subset deserves special attention, namely the macroeconomic policy indicators and governance variables used in the demand simulation. They are discussed in the next two subsections. 


\subsection{Macroeconomic policy making}

We consider three macroeconomic policy indicators for each country: the Misery Index, the government deficit or surplus, and the balance on the current account. We focus on these variables because they are eye-catching indicators of macroeconomic health. In its weekly Country Indicators page, for instance, The Economist covers the components of the Misery Index, output growth, exchange and interest rates, and the current-account and government deficit. We do not consider the effect of output growth and exchange rate changes on foreign asset demand, because they are too volatile to explain long-memory home bias.

The Misery Index, first proposed by Robert Barro in the 1970's, is the sum of a country's unemployment rate and inflation rate. There is little cross-sectional difference in official unemployment rates, except for South Africa which reports a high unemployment rate of 30 percent. Inflation rates differ more across countries and over time, with Venezuela suffering the most with inflation rates that fluctuate between 13 percent and 31 percent per year. Table 2 shows that if the host country has a high misery score, the shadow costs of investment into this country tend to be higher.

The two other macroeconomic variables, the host-country government deficit or surplus as a percentage of its GDP and the host-country's current account balance as a percentage of GDP are obtained from Datastream. The government budget was not originally included in the set of instruments of SV. Common sense suggest us to find a negative correlation between the host-country's government budget and implicit investment costs. For the pre-crisis subsample, this is indeed the case. During the credit crisis, the coefficient comes with a positive sign. In 2009, 38 out of our 42 sample countries had a deficit, with the biggest economies taking the lead: the government budget relative to GDP was -11.4 percent for Japan, -7.9 percent for the U.S. and -7.8 percent for the U.K.. The current account balance, lastly, is a special case. Deficits are generally frowned upon, but a negative current account balance means a financial surplus, possibly under the form of foreign purchases of equity which normally is a symptom of low costs to international capital flows. Again, we find coefficients with opposite signs in the subsamples. Before the crisis, we observe that a current account deficit is correlated with more foreign demand for stocks, as reflected by a lower shadow cost. During the crisis, the opposite is true: a surplus on the current account of the host country comes with lower inward investment costs.

\subsection{Political risks and transparency}

In this second group of instruments, we focus on the variables that capture the effects of political risks and of corporate and government transparency. The variables of interest here are the Transparency International Corruption Perception Index; the ENF Index, ACC Index and their interaction; the Government Effectiveness Indicator and the Corporate Board Efficacy Indicator.

We make a distinction between firm-level governance, country-level governance and the interaction effect between the two. The first measure of corporate governance is the ACC Index. This is a component of the Opacity Index developed in 2000 by PricewaterhouseCoopers 
and the Kurtzman Group, and is designed to capture the effect of accounting practices and corporate governance. ${ }^{3}$ The second corporate governance measure is the Corporate Board Efficacy Indicator, obtained from the Global Competitiveness Report. The estimation results in Table 2 show that the coefficient of the ACC Index is not significant. The Corporate Board Efficacy Indicator comes up with a significantly negative coefficient in the 2008-2009 subsample, but for the other sample years and for the pooled sample, the coefficient estimates are positive and insignificant. ${ }^{4}$ This suggests that at the aggregate portfolio level, corporate governance does not play a meaningfully beneficial role of its own in international portfolio choices. This result is in contrast with the findings of Gianetti and Simonov (2006) and Gelos and Wei (2005), who conclude that good corporate governance and protection of minority shareholders have a positive effect on international asset holdings; still, also in Gelos and Wei (2005), who study individual portfolios rather than aggregated data but make a similar distinction between corporate and government transparency, the effect of government transparency on international asset allocation is far more important than the effect of corporate transparency. Moreover, once Gelos and Wei add a series of control variables to their regressions, the corporate transparency variable is no longer significant while the government transparency variables remain highly significant. All these results are consistent with the idea that, as a stand-alone measure, corporate governance does not really help: it works only if the legal and political environment is right too (see below).

In light of our results, we focus in this paper on the effect of country-level governance on international asset allocation rather than on corporate governance, but we do include corporate governance as an interaction term. The need for an interaction term between corporate governance and country-level governance, the $\mathrm{ENF}^{*} \mathrm{ACC}$ term in SV, has been emphasized in several papers. Recall that the expected sign of the coefficient of this interaction term is debated, and the empirical findings are contradictory. On the one hand, Doidge, Karolyi and Stulz (2007) state that good government transparency, efficient legal environments and a high level of financial development are complements of good corporate governance. On the other hand, Durnev and Kim (2005) and Klapper and Love (2004) find that they seem to be substitutes. The estimation results of Table 2 are in line with the findings of Doidge et.al (2007): the coefficient estimate is significantly positive, indicating that country-level and corporate governance are complements and thus both are needed to reduce international investment costs.

We now turn to the main variables describing country-level governance. The first measure capturing country-level governance is the PwC-Kurtzmann Transparency International Corruption Perception Index (TI CPI index), first released in 1995 by Transparency International. This index ranks more than 150 countries by their perceived levels of corruption in the public sector, as determined by expert assessments and opinion surveys. Business people and analysts are questioned about the misuse of public power for private benefit, with a focus, for example,

\footnotetext{
${ }^{3}$ http://www.opacity-index.com/

${ }^{4}$ When we estimate the SV-model with the ACC Index or the Corporate Board Efficacy Indicator as single explanatory variables, their coefficient estimates are not significantly different from zero. These results can be obtained from the corresponding author.
} 
on bribe-taking by public officials in public procurement. The lower a country is scoring on the index, the more corrupt it is perceived to be. ${ }^{5}$ The countries that are perceived to be the most corrupt are Venezuela, Russia, and the Philippines, and the best scores are obtained by Sweden, New Zealand, Denmark and Singapore. The negative relation between corruption and FDI has already been documented elsewhere (Hines, 1995; Wei, 2000a, 2000b). Gray and Kaufmann (1998) and Vishwanath and Kaufmann (2001) argue that the economic costs of corruption can be substantial. Bribery raises transaction costs and uncertainty, leads to inefficient economic outcomes, impedes long-term foreign and domestic investment, misallocates talent to rent-seeking activities, and distorts sectoral priorities and technology choices. Table 2 shows that the TI CPI of the host (foreign) country correlates negatively with the shadow costs of international investments, even after controlling for items like information asymmetries, the level of development of the financial markets, transaction costs and border controls, economic development, and return skewness. This means that investors face higher implicit costs to buy stocks from countries that have a low score on the TI CPI index, that is, countries that are perceived to be more corrupt.

A second proxy for country-level governance is the ENF Index, another component of the Opacity Index. The ENF Index tries to capture the effects of the transparency of the economic policy. A higher score on the index corresponds to a higher level of opacity about the economic policy. We find that the level of opacity in economic policy-making in the host country has a significantly positive correlation with the shadow costs for foreigners to invest in that country.

A third measure for the quality of country-level governance is the Government Effectiveness Indicator developed by Kaufmann, Kraay and Mastruzzi (2006). ${ }^{6}$ This indicator captures the effect of the quality of public services, the quality of the civil service and the degree of its independence from political pressures, the quality of policy formulation and implementation, and the credibility of the government's commitment to such policies. Values on the indicator range from -2.5 to 2.5 , where a higher value indicates a better score. Government effectiveness is the lowest in Venezuela and the highest in Switzerland and Denmark. Gwartney, Holcombe and Lawson (2006) show that private investment is higher in countries with better institutional quality. Acemoglu, Johnson, Robinson and Thaicharoen (2003) show that high volatility rates

\footnotetext{
${ }^{5}$ More information on the composition of the TI CPI Index and the raw data can be obtained from http://www.transparency.org/.

${ }^{6}$ Kaufmann et al. collect data from 31 different sources and apply an unobserved components model to construct the aggregate indicator from the individual data. The Government Effectiveness Indicator is a weighted average of the underlying data, with weights reflecting the precision of the individual data sources. Interestingly, Kaufmann et al. also provide standard error estimates for their indicators. For the countries in our sample, standard errors are generally low and comparable. Other indicators developed by Kaufmann et al. are Voice and accountability, Political stability and absence of violence, Regulatory quality, Rule of law and Control of corruption. A detailed description of the variables with their sources and components can be found at www.govindicators.org.
} 
and crises periods are not so much explained by unsustainable and distortionary macroeconomic policies, but by institutional differences like the above. Thus, we expect that an improvement in the quality of public institutions has an substantial positive effect on international asset demand. The results in Table 2 confirm that there is a significantly negative correlation between the Government Effectiveness Indicator of the host country and the implicit costs of international investments.

\section{The impact of public policy on international asset demand}

In this section, we examine to what extent asset demand changes in response to an amelioration of transparency in the public sector and the overall policy of the government. We first focus on our three measures of government opacity: the TI CPI Index as a measure for corruption in the public sector, the ENF Index as an indicator of economic policy opacity and the Government Effectiveness Indicator as a measure for the quality of public institutions. We then look at our three macroeconomic policy indicators: the Misery Index, the government budget and the balance on the current account.

\subsection{Overall effects}

We express the extra foreign demand as a fraction relative to the initial market capitalization of the reforming country's stocks. This tells us by what percentage the financial wealth of nationals would rise if the extra demand just increases stock prices, or by what percentage the listed firms' equity base could increase if all extra demand would be met by new issues at unchanged prices, or a combination of both.

Table 3 summarizes the more detailed discussion below by showing the overall effect of a change in governance or macroeconomic variables on foreign demand for a country's equities. We use the (constant) pooled-sample estimates $\beta$, but $\Omega$ and $X$ change every year. For each of our sample years, the first column shows the total estimated increase in foreign demand, expressed in million USD, for the stocks of the countries where we improved one dimension of country-level governance or macroeconomic policy. The second column shows the total initial stock market capitalization of these countries and the third column contains the ratio of additional foreign demand to initial market capitalization. The table shows that the overall effect of a feasible improvement in government transparency and economic policy making can lead to an additional foreign demand of more than 80 percent of the total initial market capitalization of the group of countries. The foreign demand increase is the largest for the Government Effectiveness Index. An improvement in the macroeconomic policy indicators, leads to a smaller additional foreign demand. All these results are averages based on the pooled sample coefficient estimates of Table 2. Tables with percentage changes in inward investment costs for each year, together with figures showing the original and new inward investment costs following a change in one of the transparency variables or one of the macroeconomic policy indicators, are available on request. 
Table 3: Overall effect of an improvement in public policy on foreign equity demand This table shows total increase in demand by foreigners for equities of the countries where we improved the transparency in the public sector or a macroeconomic policy indicator. We use the (constant) pooled-sample estimates $\beta$, but $\Omega$ and $X$ change every year. For each year, the first column shows the total demand increase by foreign investors, the second column contains the initial total market capitalization for the countries with altered public policy levels and the third column contains the ratio of the first two columns. All amounts are in USD million.

\begin{tabular}{|c|c|c|c|c|c|c|}
\hline \multirow[b]{2}{*}{$\begin{array}{l}\text { policy } \\
\text { variable }\end{array}$} & \multicolumn{3}{|c|}{2005} & \multicolumn{3}{|c|}{2006} \\
\hline & $\begin{array}{r}\text { Additional } \\
\text { demand by } \\
\text { foreigners }\end{array}$ & $\begin{array}{r}\text { Initial } \\
\text { marketcap } \\
\text { equity }\end{array}$ & $(1) /(2)$ & $\begin{array}{l}\text { Additional } \\
\text { demand by } \\
\text { foreigners }\end{array}$ & $\begin{array}{r}\text { Initial } \\
\text { marketcap } \\
\text { equity }\end{array}$ & $(1) /(2)$ \\
\hline Corruption & $1,086,042$ & $4,298,661$ & 0.253 & $1,690,733$ & $6,075,612$ & 0.278 \\
\hline ENF & 913,127 & $8,090,854$ & 0.113 & $1,539,680$ & $11,257,791$ & 0.137 \\
\hline Governmnt Effect. & $3,802,731$ & $5,096,734$ & 0.746 & $6,727,505$ & $8,131,920$ & 0.827 \\
\hline Misery & 133,931 & $7,441,595$ & 0.018 & 204,221 & $10,551,416$ & 0.019 \\
\hline Governmnt budget & $-271,633$ & $30,666,884$ & -0.009 & $-384,700$ & $35,403,838$ & -0.011 \\
\hline \multirow[t]{2}{*}{ Current account } & 756,910 & $26,816,834$ & 0.028 & $1,439,660$ & $34,033,809$ & 0.042 \\
\hline & \multicolumn{3}{|c|}{2007} & \multicolumn{3}{|c|}{2008} \\
\hline $\begin{array}{l}\text { policy } \\
\text { variable }\end{array}$ & $\begin{array}{l}\text { Additional } \\
\text { demand by } \\
\text { foreigners }\end{array}$ & $\begin{array}{r}\text { Initial } \\
\text { marketcap } \\
\text { equity }\end{array}$ & $(1) /(2)$ & $\begin{array}{l}\text { Additional } \\
\text { demand by } \\
\text { foreigners }\end{array}$ & $\begin{array}{r}\text { Initial } \\
\text { marketcap } \\
\text { equity }\end{array}$ & $(1) /(2)$ \\
\hline Corruption & $3,052,348$ & $9,331,293$ & 0.327 & $1,026,551$ & $3,954,559$ & 0.260 \\
\hline ENF & $3,992,455$ & $11,077,230$ & 0.360 & $1,519,343$ & $4,913,320$ & 0.309 \\
\hline Governmnt Effect. & $10,087,773$ & $10,869,322$ & 0.928 & $4,460,555$ & $5,170,010$ & 0.863 \\
\hline Misery & 331,482 & $18,203,368$ & 0.018 & 357,908 & $5,851,016$ & 0.061 \\
\hline Government budget & $-598,851$ & $36,657,321$ & -0.016 & $-165,917$ & $21,598,720$ & -0.008 \\
\hline \multirow[t]{2}{*}{ Current account } & $2,929,316$ & $37,815,713$ & 0.077 & 765,669 & $19,892,670$ & 0.038 \\
\hline & \multicolumn{3}{|c|}{2009} & & & \\
\hline $\begin{array}{l}\text { policy } \\
\text { variable }\end{array}$ & $\begin{array}{r}\text { Additional } \\
\text { demand by } \\
\text { foreigners }\end{array}$ & $\begin{array}{r}\text { Initial } \\
\text { marketcap } \\
\text { equity }\end{array}$ & $(1) /(2)$ & $\begin{array}{c}\text { avrge } \\
(1) /(2)\end{array}$ & & \\
\hline Corruption & $1,490,942$ & $7,046,001$ & 0.212 & 0.251 & & \\
\hline ENF & $1,504,992$ & $10,389,298$ & 0.145 & 0.176 & & \\
\hline Governmnt Effect. & $6,645,413$ & $8,391,877$ & 0.792 & 0.807 & & \\
\hline Misery & 261,120 & $24,577,678$ & 0.011 & 0.027 & & \\
\hline Government budget & $-314,871$ & $29,623,138$ & -0.011 & -0.010 & & \\
\hline Current account & $1,419,575$ & $29,700,211$ & 0.048 & 0.039 & & \\
\hline
\end{tabular}

We now discuss, in turn, the effect of an improvement in each transparency variable and macroeconomic variable on the implicit costs of foreign investments and the foreign demand for a country's equities. The general picture is as follows: $(i)$ improvements in governance matter far more than further improvements in conventional macro figures; (ii) in the governance group, policy effectiveness clearly leads before corruption and transparency.

\subsection{Corruption in the public sector}

We first focus on the TI Corruption Perception Index. Figure 1 shows the original estimated shadow costs of inward investment using the coefficient estimates from Table 2, and the new shadow costs after a change in the level of perceived corruption in the public sector, averaged over the full sample period 2005-2009. Figures for the individual years are available on request. Our main interest is in the final impact on demand, though. Table 4 shows the results.

We first note that, when the perceived level of government corruption is lowered, the additional demand by foreigners for a country's equities can be very substantial. For example, 


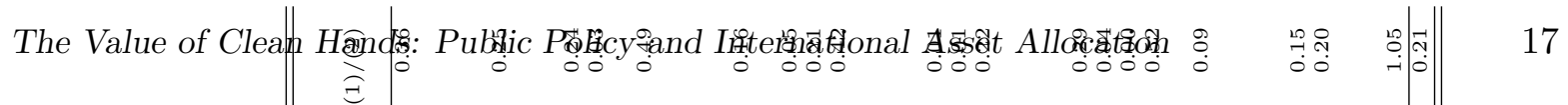

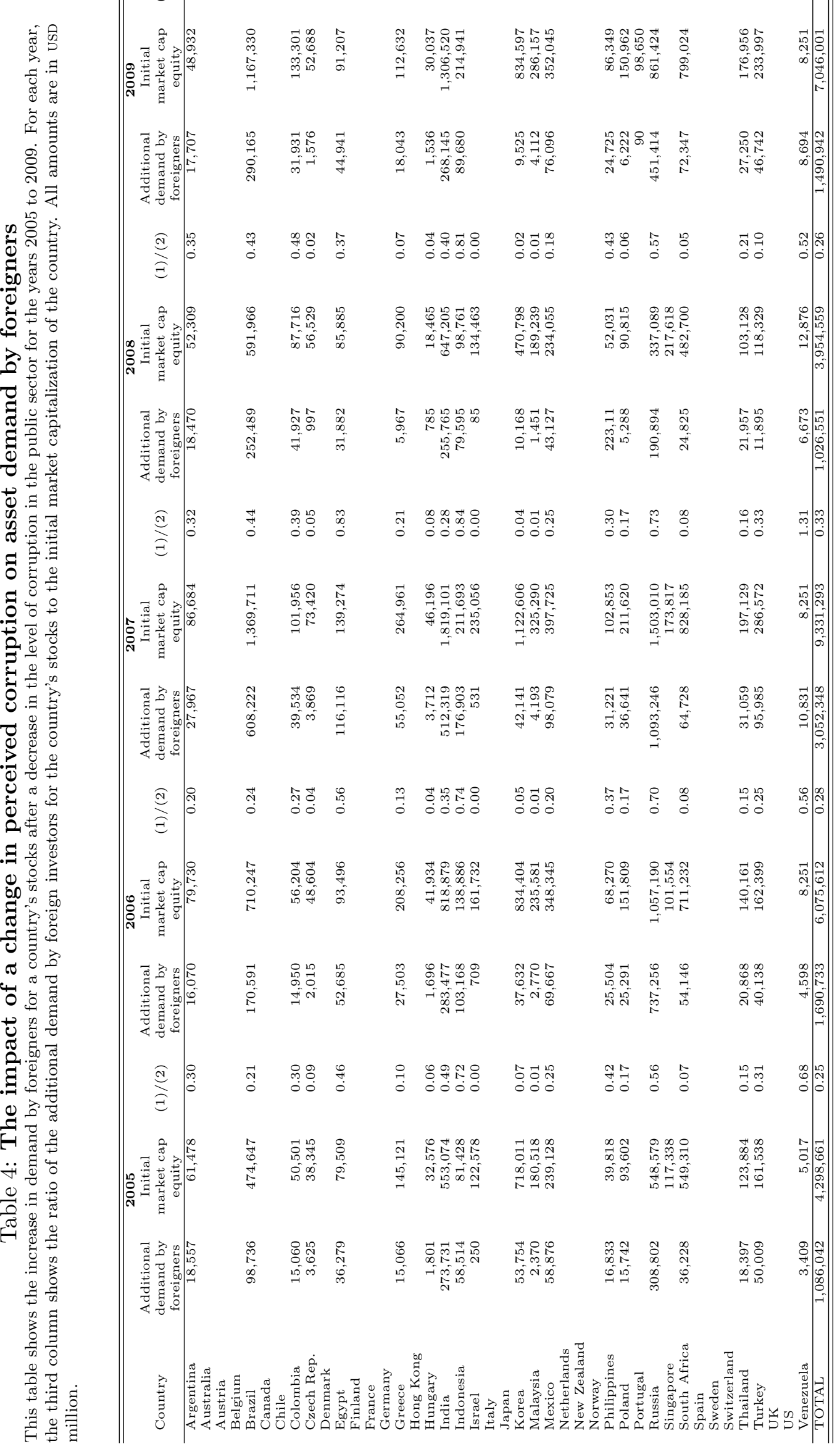


Figure 1: Original and new average inward investment costs after a change in the level of perceived corruption.

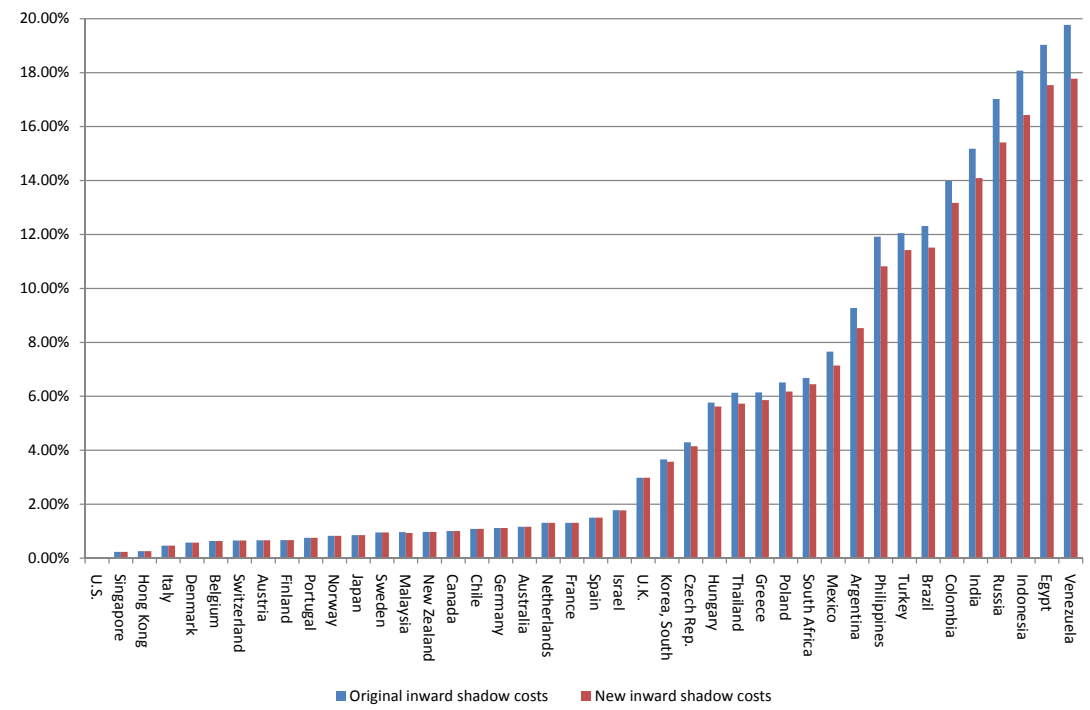

the estimated increase in demand by foreigners for equities of Argentina in 2005 equals USD 18,557m, 30 percent of the total stock market capitalization of Argentina for that year end. For Venezuela, Indonesia, India, Egypt, Russia and the Philippines, the effects are even larger. These estimates may seem unrealistic at first sight, but they reflect the relatively small initial market capitalizations of these countries. If for example U.S. investors would decide to invest $1 \%$ of their total wealth in Venezuela in response to a putative decrease in public corruption in that country, the total dollar amount of this additional foreign demand would be far larger than the initial market capitalization of Venezuela. Actual growth rates of emerging countries' stock markets can be very large. Vietnam's stock market capitalization, for instance, has risen from USD 400 million in early 2006 to around USD 22 billion in March 2007. This was not all caused by increases in stock prices: while the P/E of the market's top 20 firms was an impressive 70, Vietnam's market capitalization would still be usD 12 billion, 30 times its value one year ago, if the P/Es had been lowered to, for example, 20 (the level of India). ${ }^{7}$ Still, since growth rates from a small starting basis are noisy, it seems advisable to look at total extra demand across all countries, as a fraction of their aggregated initial market cap, rather than at individual growth rates. For example, for 2009 the total increase of foreign equity demand following a feasible decrease in the perceived level of public corruption is estimated at USD $1,490,942 \mathrm{~m}$, i.e. 21 percent of the total initial market capitalization of the countries where the level of perceived government corruption is worse than the median.

\footnotetext{
${ }^{7}$ The Economist, March 15th 2007.
} 
Figure 2: Original and new average inward investment costs after a change in the level economic policy opacity.

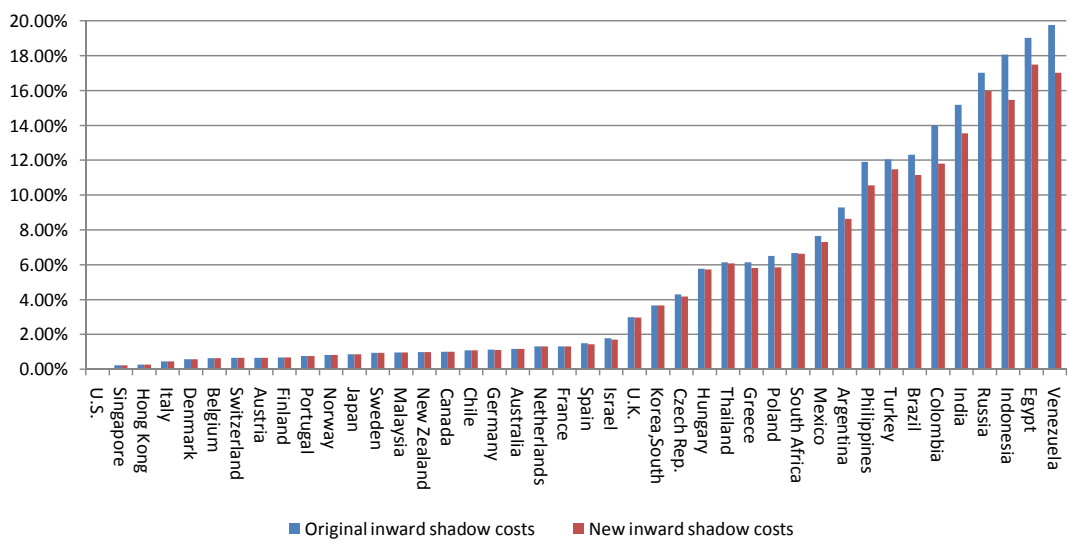

The foreign demand increases calculated using the yearly coefficient estimates, can be considerably different from the ones based on the pooled sample estimates. Yearly coefficient estimates are likely to contain more noise and coincidental factors, but still they are interesting in se and the general picture remains the same: our calculations indicate that the perceived level of corruption in the host country can be very influential for foreign investor confidence and a reduction in government corruption should create large foreign inward investments.

In the next section, we turn to the effect of a change in economic policy opacity on the shadow costs of international investments and international asset allocation. As of this point, tables of year-by-year calculations of country-by-country impacts are omitted; they are available on request.

\subsection{Economic policy opacity}

Figure 2 shows the average change in the shadow costs of inward investments after an improvement of the transparency in economic policy-making. The main effect of this variable is positive and enforced by the positive interaction term with corporate governance. The effect of an amelioration of economic policy transparency in opaque countries lowers the inward investment costs similarly as an improvement in corruption control. For India, the average (over five years) of the inward investment costs drops by 11 percent, that is a decrease from 15.2 to 13.5 percent per annum. The cost reduction is the most pronounced for Venezuela, the country that scores worst on the index of economic policy opacity. Shadow costs of inward investment 
in Indonesia on average change from 19.8 to 17.0 percent per annum.

The impact of transparency of economic policies on international equity demand is comparable to the impact of changes in perceived corruption. Exceptionally high demand changes are again observed for Venezuela, Indonesia, Egypt and the Philippines because of the small initial market capitalizations of these countries and the bad initial scores (i.e. the large assumed changes).

Aggregated over all countries in 2009, the additional foreign equity demand is estimated at USD $1,504,992 \mathrm{~m}$, or 14 percent of the total initial market capitalization of the countries with initially non-transparent economic policy. The additional foreign demand for 2005, 2006, 2007 and 2008 is estimated at respectively 11 percent, 14 percent, 36 percent and 31 percent of total initial market capitalization.

We turn to our third country-level governance measure, the Government Effectiveness Indicator.

\subsection{Government effectiveness}

Figure 3 shows the corresponding initial and new implicit costs of inward investments when the Government Effectiveness Indicator is improved. An improvement in institutional quality leads to substantial reductions in the shadow costs of inward investments. The reduction in implicit investment costs is the largest for Venezuela (-49.2\%), a drop from 19.8 percent to 10.1 percent, and the smallest for South Korea $(-0.45 \%)$. In a more middle-of-the road example like Greece, average inward investment costs drop from 6.1 percent per annum to 5.3 percent per annum.

For several emerging countries, the additional demand exceeds their initial market capitalization significantly. For example, in 2009, the additional foreign demand towards Egypt's equities is estimated at USD 207,826 , while its market capitalization is only USD $91,207 \mathrm{~m}$. Overall, the improvement in the Government Effectiveness Indicator leads to an additional foreign demand that amounts up to an impressive 79 percent of the initial market capitalization of the countries with bad quality of public institutions in 2009 and to 93 percent of total initial stock market cap in 2007 - by large the biggest effect among all we looked at. Although these estimates are only indicative, our results indicate the importance of institutional quality in particular and a good and transparent public policy in general for international portfolio allocation and the development and growth of the financial markets, especially for emerging markets.

Lastly, we turn to the three macroeconomic policy indicators, the Misery Index, the government deficit or surplus and the balance on the current account. This enables us to compare the effects of transparency variables to those of traditional macroeconomic variables. 
Figure 3: Original and new average inward investment costs after a change in the level of government effectiveness.

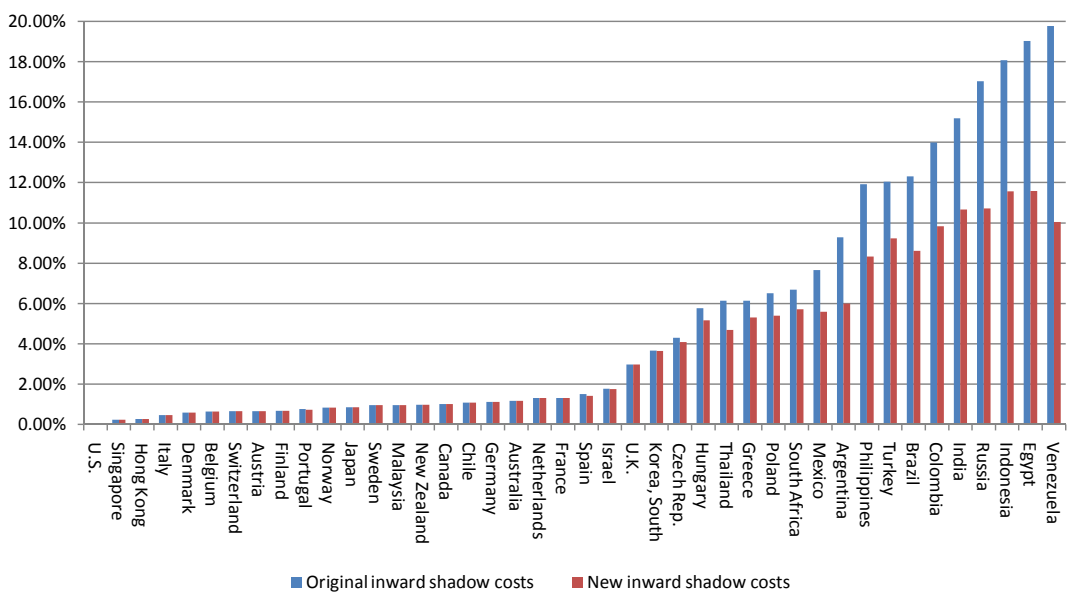

\subsection{Misery Index}

Figure 4 shows that a moderate reduction of the Misery Index has a substantially smaller effect on the shadow costs of inward investments than the pure transparency variables. The biggest

Figure 4: Original and new average inward investment costs after a change in the level of the Misery Index.

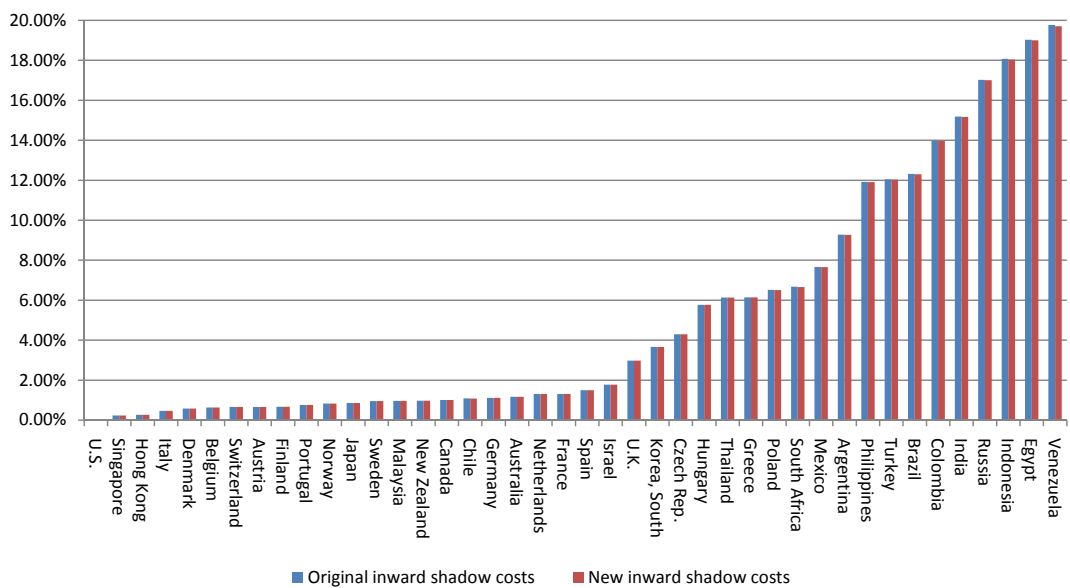


impact is in Venezuela, where inflation rates were particularly high during our sample period. However, inward investment costs drop only 0.31 percent, from 19.8 percent to 19.7 percent per annum.

Predictably, in light of the lower effect on $\operatorname{costs} C^{l}$, the impact of lowering the Misery Index is less spectacular than the impact of an improvement in government transparency. We find that the additional demand by foreign investors is low (ranging between 1.1 percent of total initial market cap in 2009 to 6.1 percent of initial market cap in 2008), especially compared to the additional foreign demand resulting from the improvement in the Government Effectiveness indicator.

\subsection{Government deficit or surplus}

The second macroeconomic policy indicator that we consider is the government surplus or deficit as a percentage of a country's GDP. This variable does not have a consistent effect over our five sample years. Figure 5 shows the percentage decrease in the shadow costs of inward investment after a small decrease in the government deficit for the pooled sample. As the coefficient estimate is positive, an improvement in the government balance comes with a - small - increase in inward investment costs. Figure 6 shows the average change in costs for the precrisis and crisis periods. Before the credit crisis, a decrease in the government's deficit resulted in a decrease inward investment costs, as one would expect, however the change in shadow

Figure 5: Original and new average inward investment costs after a decrease in the government deficit.

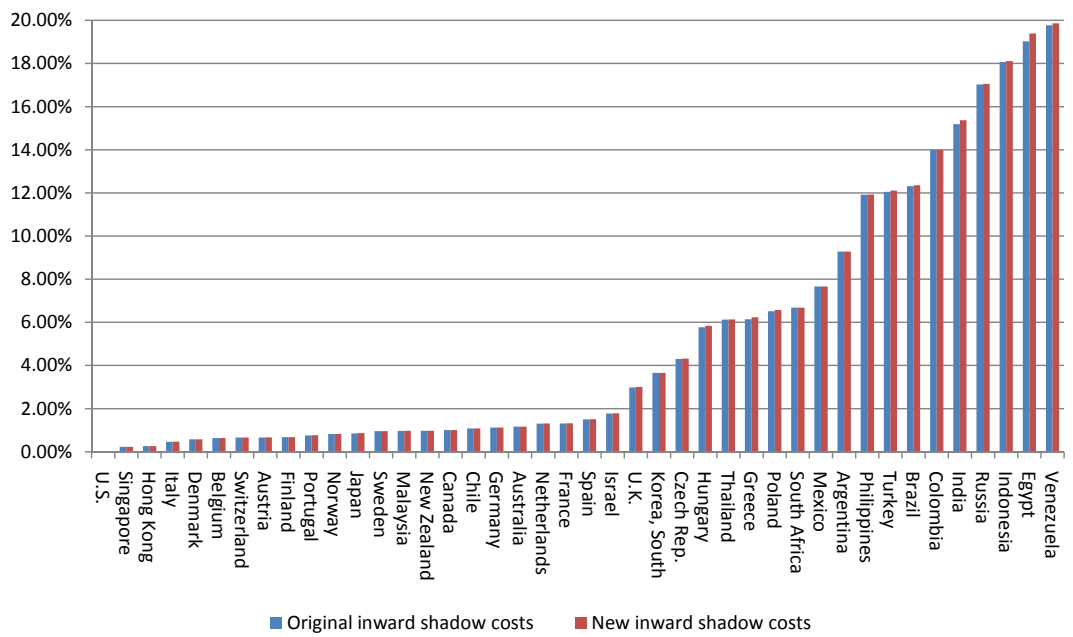


costs is limited, Indonesia being the only exception. On top of that, it is important to note that many cost reductions are for initially low-cost countries such the U.S., France, Germany and Italy. These are countries with already well developed and large financial markets. For example, the cost decrease of 0.64 percent in the Germany corresponds to a drop in implicit investment costs from 0.510 percent per annum to 0.507 percent per annum, which is very small in absolute figures and cannot lead to meaningful inflows of foreign capital.

Figure 6: Original and new average inward investment costs after a decrease in the government deficit over the subsamples.

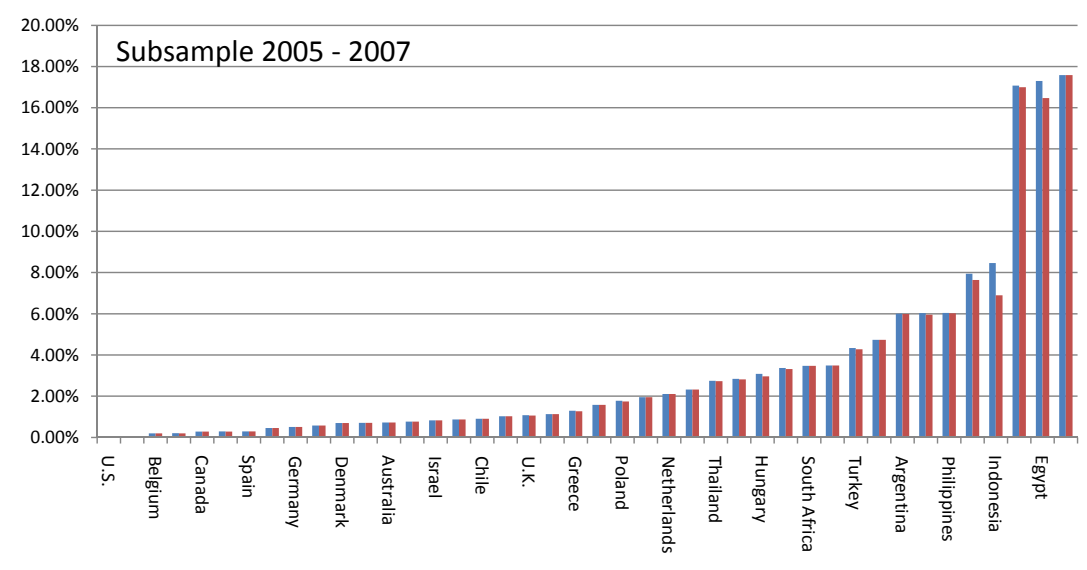

@ Original inward shadow costs $\quad$ New inward shadow costs

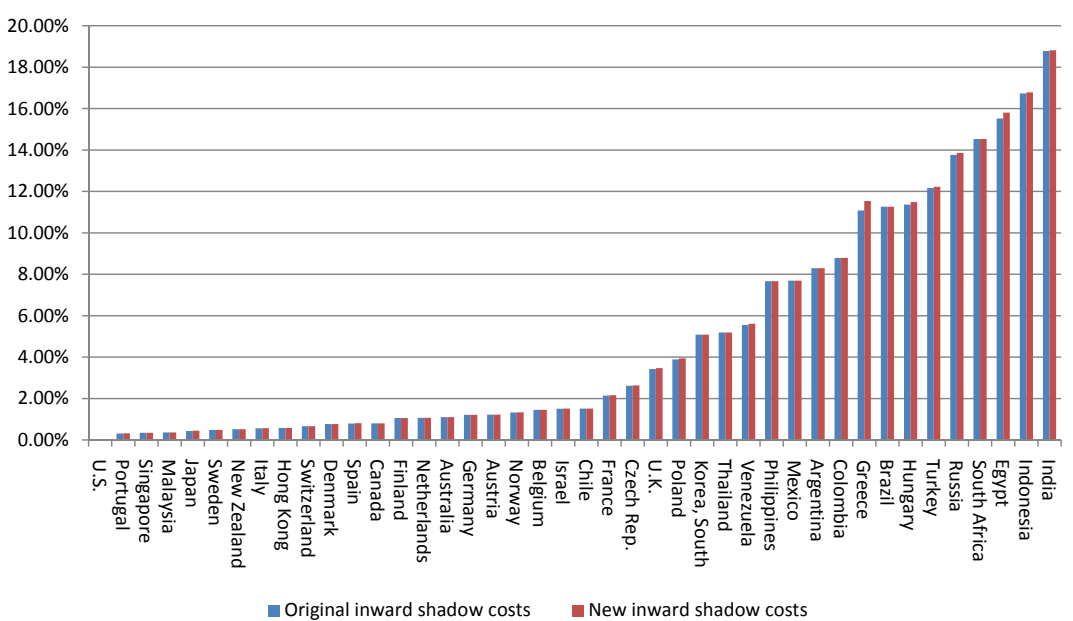


Figure 7: Original and new average inward investment costs after a decrease in the current account deficit.

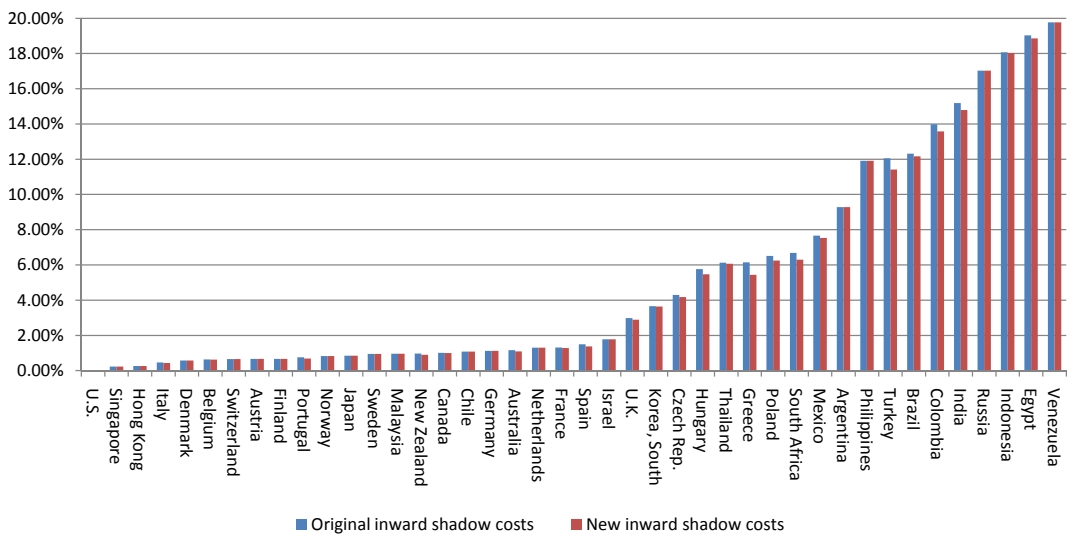

During the crisis most countries showed large government deficits, the developed markets upfront. For this period, we find that a decrease in the government deficit increases investment costs, although this increase is again very limited. In general, we can conclude that, whatever is the direction, there is only a minimal impact in implicit investment costs in response to an improvement in the government budget of the host country.

When we again compute the change in foreign asset demand after a decrease in the government deficit for countries with initially large deficits, the effect is small compared to the initial market capitalization of these countries, and never exceeds 2 percent of the total initial market cap. A probable explanation is that the the cross-country differences in government deficit or surplus are small and deficits are not confined to developing countries.

Lastly, we turn to our third macroeconomic policy indicator, the balance on the current account.

\subsection{Current account deficit or surplus}

Figure 7 shows the percentage decrease in the implicit costs of investments following a decrease in the current account deficit for the countries with an initially negative balance on their current account. The effect is minimal. The biggest impact is found for Greece: inward investment costs drop with 11.5 percent, from 6.14 to 5.44 percent per annum, after an improvement in the current account balance. All other countries show smaller effects. For example, for Canada inward investment costs drop from 1.01 to 1.00 percent per year. 
The estimates of the increase in foreign equity demand following an improvement in the current account balance indicate that foreign investors' demand for a country's equities is only mildly affected if the deficit on the current account in the host-country decreases. The main exception is Greece, where increases in foreign equity demand amount up to 1.3 times the initial market capitalization in 2007. On average, the total increase in foreign equity demand following an improvement in the current account balance ranges from 3 percent of total market cap in 2005 over 4 percent in 2006 and 2008, to 8 percent of total initial stock market capitalization in 2007. Notice that for this variable, we observe a different impact for our two subsamples. Before (during) the financial crisis, a deficit on the current account was positively (negatively) correlated with inward investment costs.

\subsection{Robustness check: additional foreign demand in dollars not percentages}

We have measured the impact as the percentage rise in foreign demand for a country's stock as a percentage. This yardstick obviously depends on the initial size of the county's stock market. One potential problem is that, for each policy variable, the list of reforming countries differs; thus, the percentage increase in wealth is not necessarily comparable across policy measures: the ratio of foreign demand change to initial stock market cap for one measure can be larger because the reforming countries are smaller. Therefore, as a robustness check, we have also considered the total dollar amounts of extra demand, which is independent of the country mix and the size of the reforming country.

Figure 8 shows the magnitude of the effect of a feasible improvement in each of our governance and macroeconomic variables on the demand of foreigners for a country's equities. For each sample year, the figure shows the total increase in foreign equity demand in millions of USD, following an improvement in one of the variables for the countries that score worse than the median on that particular governance measure or macroeconomic policy indicator. We observe from Figure 8 that the results as reported above remain valid: the demand effect following a change in the Government Effectiveness Indicator is consistently the largest. An improvement in the perceived corruption in the public sector TI CPI or in economic policy transparency does also lead to a seizable substantial increase in foreign equity demand. The effect of an improvement in the traditional macroeconomic variables is considerably lower: the demand effect of an improvement in the Misery Index is at least ten times smaller than the effect of a similar improvement in transparency variables, and the demand effect of a decrease in the government deficit is even less significant. An improvement in the current account balance leads to a comparable inflow in foreign equity demand than an improvement in corruption control or economic policy transparency. However, remember that this variable isn't consistent over time. 
Figure 8: Overall effect of an improvement in public policy.

This figure shows the overall effect of an improvement in our three public governance variables - notably the TI Corruption Perception Index (TI CPI), the ENF Index (ENF) and the Government Effectiveness Indicator (Gov Eff) - and our three macroeconomic policy indicators, the Misery Index (Misery), the government deficit or surplus and the current account deficit or surplus on the foreign demand towards a countries equities. All figures are in USD million and the estimates are based on the pooled sample estimates from Table 2.

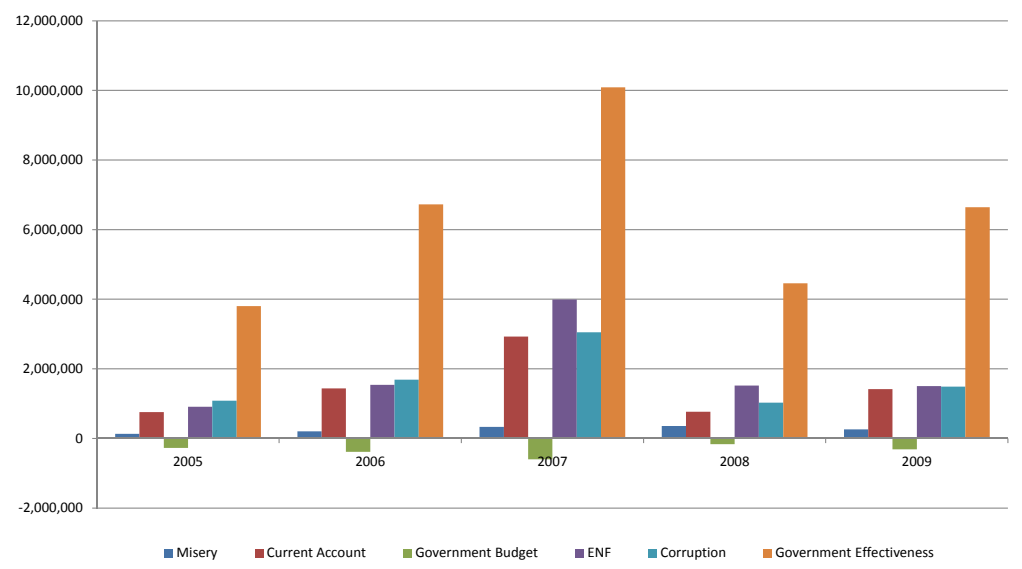

\section{Conclusion}

This paper illustrates the general importance of good governance at the country level for financial development and foreign equity investments and tries to identify the fields where action would be most effective. This study differs from earlier work on the effects of government transparency on international asset allocation in that it uses portfolio theory rather than an ad hoc regression approach. We first consider a specific set of governance dimensions (perceived corruption in the public sector, economic policy opacity and a government effectiveness index measuring the quality of public institutions) and we calculate the additional foreign demand for a country's equities after a feasible improvement in one of the public governance variables. These results for the governance variables are then compared to the results of an improvement in one of three macroeconomic variables, notably the Misery Index, the government deficit and the balance on the current account. Our results support the recently growing idea that the benefits from financial liberalization for developing countries can only occur if government transparency is improved. Low levels of corruption and high quality institutions have a positive effect on investor confidence and can be an important driver to attract foreign capital. The sign of the interaction effect between country-level and firm-level governance is positive, indicating that country-level and corporate governance are complements. This confirms the results of Doidge, Karolyi and Stulz (2007).

The main conclusion of this paper is that more transparent policy-making and improving 
the quality of public institutions seem to be more efficient at attracting foreign investment than an active public policy that lowers unemployment or inflation rates or reduces the government budget deficit, especially for the emerging markets. Cross-country differences in macroeconomic policy indicators are smaller than cross-country differences in transparency and public governance. One reason may very well be that the emerging markets in the sample have already adopted better policies by tackling inflation rates, unemployment rates and deficits, while they are still far away from the developed markets with respect to institutional quality and transparency. More transparency in the public sector, a lower perceived level of corruption and, first and foremost, more effective public institutions are important factors in reducing information costs and in building confidence with foreign investors. Our results confirm earlier research on corruption, transparency and institutional quality that conclude that government corruption and public policy opacity can be a large burden on economic growth and financial globalization (Wei, 2000 and Stulz, 2005). The increased foreign demand towards a country's equities is likely to create a similar increase in welfare for the inhabitants. First, the greater foreign demand can lead to a hike in stock prices. Second, the demand increase will probably be followed by new equity issues. And third, a larger foreign equity demand and thus increased foreign ownership in firms can have a significant impact on the firm's performance: firm valuation ratios such as book-to-market of the Tobin's Q ratio are likely to improve improve (Sarkissian and Schill, 2004; Ferreira and Matos, 2006). 


\section{Appendix}

\section{A.1 The Bekaert-Harvey time-varying volatility model}

Bekaert-Harvey (1997) model is expressed by following set of equations:

$$
\begin{aligned}
r_{l, t} & =\mu_{l, t-1}+\varepsilon_{l, t}, \\
\varepsilon_{l, t} & =\nu_{l, t-1} \varepsilon_{w, t}+e_{l, t}, \\
\left(\sigma_{l, t}^{\prime}\right)^{2} & =E\left[e_{l, t}^{2} \mid I_{t-1}\right]=c_{l}+\alpha_{l}\left(\sigma_{l, t-1}^{\prime}\right)^{2}+\beta_{l} e_{l, t-1}^{2}+\gamma_{l} S_{l, t} e_{l, t-1}^{2}, \\
e_{t, l} & =\sigma_{l, t}^{\prime} z_{l, t},
\end{aligned}
$$

where $r_{l}$ represents the excess equity return of country $l, I_{t-1}$ is the information available at time $t-1$ and $\mu_{l, t-1}$ denotes conditional mean return for country $l$. The unexpected portion of country's l's return, $\varepsilon_{l, t}$, is driven by world shocks, $\varepsilon_{w, t}$ and a purely idiosyncratic shock, $e_{l, t}$. The dependence of local shocks on world shocks is determined by $\nu_{l, t-1}$. The local idiosyncratic standard deviation is $\sigma_{l, t}^{\prime}$ and $z_{l, t}$ is a standardized residual with zero mean and unit variance. $S_{l, t}$ is an indicator variable that is equal to unity when the idiosyncratic shock is negative and zero otherwise. Equations (10) to (13) are the expression of a TGARCH $(1,1)$ model which accounts for asymmetries in the volatility of equity returns. The mean $\mu$ and the sensitivities to shocks $\nu$ are modeled as

$$
\begin{aligned}
\mu_{l, t-1} & =\delta_{l, 1}^{\prime} X_{l, t-1}+\delta_{l, 2}^{\prime} X_{t-1}, \\
\nu_{l, t-1} & =q_{l, 0}+q_{l, 1}^{\prime} X_{l, t-1}^{*},
\end{aligned}
$$

where $X_{t-1}$ represents a set of world information variables including a constant, the world market dividend yield in excess of the 30-day Eurodollar rate, the default spread (Moody's Baa minus Aaa bond yields), the change in the term structure spread (US ten-year bond yield minus three-month T-bill yield), and the change in the 30-day Eurodollar rate. $X_{l, t-1}$ is a set of local information variables: a constant, the equity return, the exchange rate, the dividend yield, the ratio of equity market capitalization to GDP, and the ratio of trade (exports plus imports) to GDP. $X_{l, t-1}^{*}$ contains market cap to GDP and trade to GDP, which should capture the degree of integration of a country in the world market. All information variables are lagged.

The Bekaert-Harvey model is estimated in two steps. In the first step, we estimate the model for the world market return. If we apply the model in equations (10)-(13) to the world market return, we obtain a special case where $l=w, \sigma_{l, t}^{\prime}=\sigma_{w, t}, \nu_{w, t-1}=0$ and $\mu_{w, t-1}=\delta_{w}^{\prime} X_{t-1}$.

In the second step, we estimate the model country by country, conditioning on the world market estimates. We consider two different distributional assumptions for the standardized residuals, the standard normal and the t-distribution (to accommodate fat tails). We report only the results of the model that scores best on the Pagan-Schwert (1990) test. ${ }^{8}$

\footnotetext{
${ }^{8}$ Following Pagan and Schwert (1990), we regress the squared residuals onto the estimated variances and select the model with the highest $R^{2}$.
} 
The Value of Clean Hands: Public Policy and International Asset Allocation

A.2 Year-by-year estimation results 
The Value of Clean Hands: Public Policy and International Asset Allocation

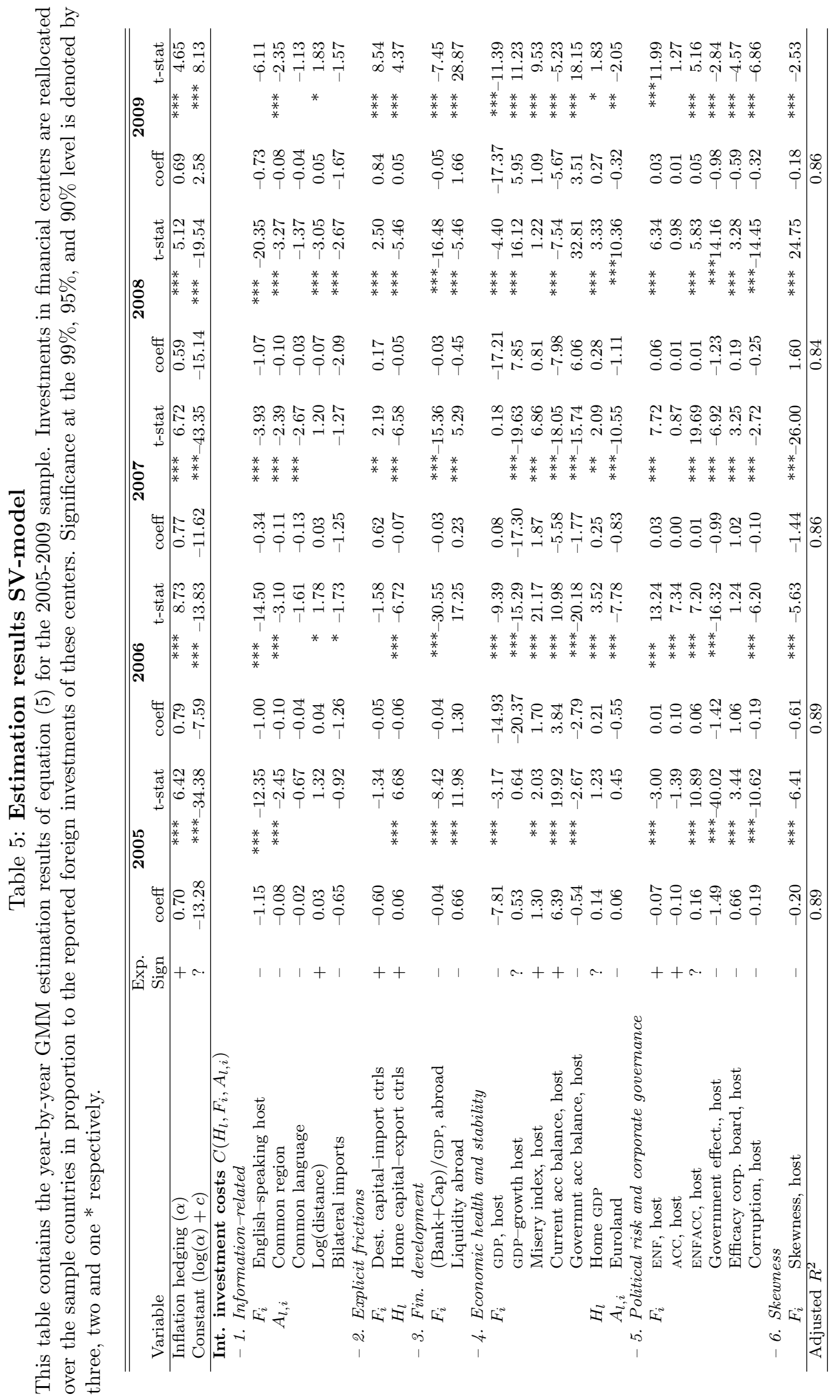


The Value of Clean Hands: Public Policy and International Asset Allocation

\section{References}

[1] Acemoglu, D., S. Johnson, J. Robinson and Y. Thaicharoen, 2003, Institutional causes, macroeconomic symptoms: volatility, crisis and growth, Journal of Monetary Economics 50, 49-123.

[2] Bekaert, G. and C.R. Harvey, 1997, Emerging equity market volatility, Journal of Financial Economics 43, 29-77.

[3] Beltratti, A. and R.M. Stulz, 2009, Why Did Some Banks Perform Better during the Credit Crisis? A Cross-Country Study of the Impact of Governance and Regulation, ECGI Finance Working Paper N 254-2009.

[4] Berkel, Barbara, 2004, Institutional Determinants of International Equity Portfolios - A CountryLevel Analysis, MEA discussion paper 0461, Mannheim Research Institute for the Economics of Aging, University of Mannheim.

[5] Bhattacharya, U., H. Daouk and M. Welker, 2003, The world price of earnings opacity, Accounting Review 78, 641-678.

[6] Black, B., 2001, The corporate governance behavior and market value of Russian firms, Emerging Markets Review 2, 89-108.

[7] Bollerslev, T., 1990, Modelling the coherence in short-run nominal exchange rates: a multivariate generalized ARCH model, Review of Economics and Statistics 72.3, 498-505.

[8] Chan, K., Covrig, V., Ng, L., 2005, What Determines the Domestic Bias and Foreign Bias? Evidence from Mutual Fund Equity Allocations Worldwide, Journal of Finance 60.3, 1495-1534.

[9] Choe, H., BC Kho, and R.M. Stulz, 1999, Do foreign investors destabilize stock markets? The Korean experience in 1997, Journal of Financial Economics 54.2, 227-264.

[10] Cooper, I.A. and E. Kaplanis, 1994, Home Bias in Equity Portfolios, Inflation Hedging, and International Capital Market Equilibrium, Review of Financial Studies 7.1, 45-60.

[11] Cooper, I.A. and E. Kaplanis, 2000, Partially segmented international capital markets and international capital budgeting, Journal of International Money and Finance 19, 309-329.

[12] Coval, J. and T. Moskowitz, 1999, Home bias at home: Local equity preference in domestic portfolios, Journal of Finance 54.6, 2045-2073.

[13] Dahlquist, M., L. Pinkowitz, R. Stulz and R. Williamson, 2003, Corporate Governance and The Home Bias, Journal of Financial and Quantitative Analysis, 38.1, 87-110.

[14] Doidge, C., G.A. Karolyi and R. M. Stulz, 2007, Why do countries matter so much for corporate governance?, Journal of Financial Economics, 86.1, 1-39. 
The Value of Clean Hands: Public Policy and International Asset Allocation

[15] Durnev, A. and E.H. Kim, 2005, To Steal or Not to Steal: Firm Attributes, Legal Environment, and Valuation, Journal of Finance 60.3, 1461-1493.

[16] Eichengreen, B., 2004, Financial Instability, Copenhagen Consensus Challenge Paper, available at http://www.copenhagenconsensus.com/

[17] Erkens, D., M. Hung and P. Matos, 2009, Corporate Governance in the 2007-2008 Financial Crisis: Evidence from Financial Institutions Worldwide, ECGIFinance Working Paper.

[18] Faruqee, H., S. Li and I.K. Yan, 2004, The Determinants of International Portfolio Holdings and Home Bias, IMF Working Paper, WP/04/34.

[19] Fergusson, L., 2006, Institutions for financial development: What are they and where do they come from?, Journal of Economic Surveys 20.1, 27-69.

[20] Ferreira, M.A. and P.P. Matos, 2006, The Colors of Investors' Money: The Role of Institutional Investors Around the World, Working Paper, University of Southern California.

[21] Fidora, M., M. Fratzscher and C. Thimann, 2007, Home bias in global bond and equity markets: the role of real exchange rate volatility, Journal of International Money and Finance 26.4, 222-225.

[22] Gelos R.G., and S-J Wei, 2005, Transparency and International Portfolio Holdings, Journal of Finance 60.6, 2987-3020.

[23] Giannetti, M. and A. Simonov, 2006, Which Investors Fear Expropriation? Evidence from Investor's Portfolio Choices, Journal of Finance 61.3, 1507-1547.

[24] Gray, C.W. and D. Kaufmann, 1998, Corruption and Development, Finance $\& 3$ Development, March $1998,7-10$.

[25] Gwartney, J.D., R.G. Holcombe and R.A. Lawson, 2006, Institutions and the Impact of Investment on Growth, Kyklos 59.2, 225-273.

[26] Hellman, J.S., G. Jones and D. Kaufmann, 2003, Seize the state, seize the day: State capture and influence in transition economies, Journal of Comparative Economics 31.4, 751-773.

[27] Hines, J.R., 1995, Forbidden Payment: Foreign Bribery and American Business after 1977, Working Paper 5266, Cambridge, Mass, National Bureau of Economic Research.

[28] Johnson, S., P. Boone, A. Breach, E. Friedman, Corporate governance in the Asian financial crisis, 2000, Journal of Financial Economics 58, 141-186.

[29] Karolyi, G.A. and R.M. Stulz, 2003, Are Financial Asset Priced Locally or Globally?, in the Handbook of the Economics of Finance, G. Constantinides, M. Harris, and R.M. Stulz, eds. Elsevier North Holland, 2003.

[30] Kashyap, A., R. Rajan, and J. Stein, 2008. Rethinking Capital Regulation. Working paper, University of Chicago. 
[31] Kaufmann, D., A. Kraay and M. Mastruzzi, 2006, Governance Matters V: Aggregate and Individual Governance Indicators for 1996-2005, The World Bank (September 2006), Available at SSRN: http://ssrn.com/abstract=929549.

[32] Kho, B-C, R.M. Stulz and F.E. Warnock, 2009, Financial globalization, governance and the evolution of the home bias, Journal of Accounting Research 47.2, 597-635.

[33] Kirkpatrick, G., 2009, The Corporate Governance Lessons from the Financial Crisis, Financial Markets Trends, OECD 2009.1.

[34] Klapper, L.F. and I. Love, 2004, Corporate governance, investor protection, and performance in emerging markets, Journal of Corporate Finance 10.5, 703-728.

[35] Lane, Philip and G.M. Milesi-Ferretti, 2004, International Investment Patterns, IMF Working Paper $04 / 134$.

[36] Lane, Philip and G. M. Milesi-Ferretti, 2005, The International Equity Holdings of Euro Area Investors, IIIS Discussion Paper 104.

[37] La Porta, R., F. Lopez-de-Silanes, A. Shleifer and R. Vishny, 1998, Law and Finance, Journal of Political Economy 106, 1113-1155.

[38] La Porta, R., F. Lopez-de-Silanes, A. Shleifer and R. Vishny, 1999, Corporate ownership around the world, Journal of Finance 54, 471-517.

[39] La Porta, R., F. Lopez-de-Silanes, A. Shleifer and R. Vishny, 1999, The Quality of Government, Journal of Law, Economics and Organization 15.1, 222-279.

[40] Lewis, K. K., 1999, Trying to explain home bias in equities and consumption, Journal of Economic Literature 37.1, 571-608.

[41] Longin, F. and B. Solnik, 1995, Is the correlation in international equity returns constant: 19601990?, Journal of International Money and Finance 14.1, 3-26.

[42] Prasad, E., K. Rogoff, S-J Wei and M.A. Kose, 2003, Effects of Financial Globalization on Developing Countries: Some Empirical Evidence, IMF, Washington D.C.

[43] Portes, R. and H. Rey, 2005, The determinants of cross-border equity flows, Journal of International Economics 65.2, 269-296.

[44] Rammal, H.G. and R. Zurbruegg, 2006, The impact of regulatory quality on intra-foreign direct investment flows in the ASEAN markets, International Business Review 15, 401-414.

[45] Sarkassian, S. and M. J. Schill, 2004. The overseas listing decision: new evidence of proximity preference, Review of Financial Studies 17, 769-809

[46] Sercu, P. and R. Vanpée, 2008, Estimating the Costs of International Equity Investments, Review of Finance 12.4, 587-634. 
[47] Shleifer, A. and R. Vishny, 1997, A survey of corporate governance, Journal of Finance 52, 737-783.

[48] Stulz, R.M., 2005, The Limits of Financial Globalization, Journal of Finance 60.4, 1595-1638.

[49] Vishwanath, T. and D. Kaufmann, 2001, Toward Transparency: New Approaches and Their Application to Financial Markets, The World Bank Research Observer 16.1, 41-57.

[50] Wei, S-J., 2000a, How Taxing Is Corruption on International Investors, Review of Economics and Statistics, 82.1, 1-11.

[51] Wei, S-J., 2000b, Local corruption and global capital flows, Brookings Papers on Economic Activity $2,303-354$.

[52] Woo, W.T., 2004, Serious Inadequacies of the Washington Consensus: Misunderstanding the Poor by the Brightest, in Diversity in Development, Reconsidering the Washington Consensus, J.J. Teunissen and A. Akkerman, Forum on Debt and Development (FONDAD), The Hague.

[53] Wyplosz, C., 2004, Financial Instability in Emerging Market Countries: Causes and Remedies, in Diversity in Development, Reconsidering the Washington Consensus, J.J. Teunissen and A. Akkerman, Forum on Debt and Development (FONDAD), The Hague. 